\title{
Contents, Vol. 1, 1975
}

International Journal for

\author{
Editor: \\ York, N.Y. \\ Editorial Board: \\ 0. Hagnell, Lund \\ J.D. Rainer, \\ J. Angst, Zurich \\ T. Helgason, Reykjavik \\ New York, N.Y. \\ O.H. Arnold, Vienna \\ P. Janssens, Beerse \\ E. Ringel, Vienna \\ C. A strap, Tromse \\ M. Jouvet, Lyon \\ E.J. Sacchar, Bronx, N.Y.

\section{T.A. Ban, Montreal,}

M. Sandier, London

Quebec

N. Sartorius, Geneva

J.R. Boissier, Paris
M. Lipton,

M. Schou, Risskov

Chapel Hill, N.C.

P. Deniker, Paris

J.J. Lopez Ibor, Madrid

J.E. Desmedt, Brussels

P. Mandel, Strasbour

1. Shields, London

N. Matussek, Munich

J.R. Smythies, Edinburgh

Alberta

H. Mitsuda, Osaka

E. Strömgren, Risskov
J. Mendlewicz, Brussels/New

J. de Ajuriaguerra, Geneva

D. Kupfer, Pittsburgh, Pa.

M. Levitt, New York, N.Y.

J.M. Davis, Chicago, 111.

F. Schulsinger, Copenhagen

C. Shagass, Philadelphia, Pa 
A. Dresse, Liè̀ge

T. Nagatsu, Nagoy

R. Tissot, Geneva

C.M.B. Pare, London

J. Dwell, Washington, D.C

L. Valzelli, Milan

E.C. Elston

E.S. Paykel, London

H.M. Van Praag, Groninge

Chapel Hill, N.C,

M. Vartanian, Moscow

J.M. Perel, New York, N.Y

C. Perris, Umeå

o. Vinar, Prague

P. Pichot, Paris

M. Vojtëchovsky, Prague

S. Garattini, Milan

A.J. Prange, jr.,

G. Winokur,

L.R. Gjessing, Oslo

Chapel Hill, N.C.

Iowa City, Iowa

J. Glowinski, Paris

O.J. Rafaelsen,

P. Grof, Hamilton, Ontario

Copenhagen

A 


\section{S. Karger $\cdot$ Basel $\cdot$ München $\cdot$ Paris $\cdot$ London $\cdot$ New York $\cdot$ Sydney}

Index

No. 1

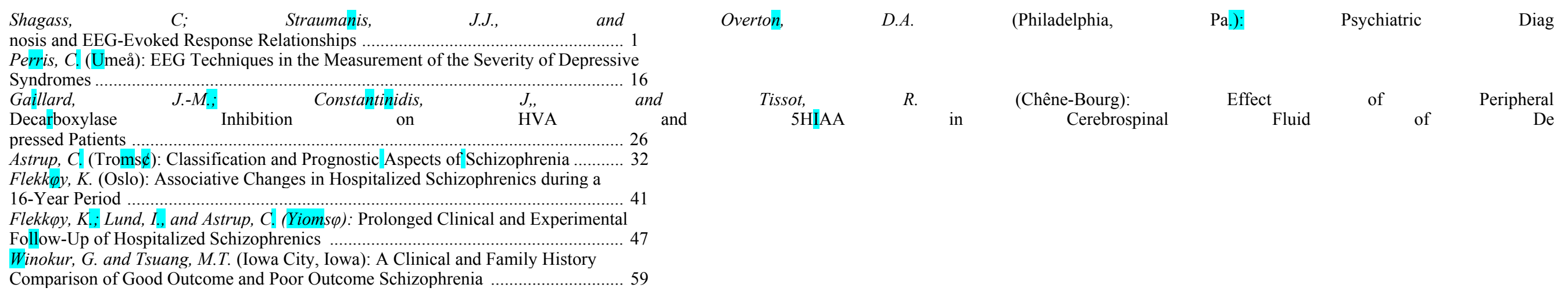

No. 2

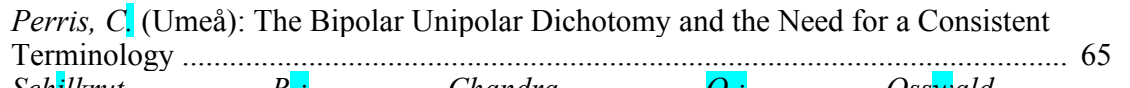
Schilkrut,

(München):

R.; Chandra

Hormone

$M$

in Depressed Patients ...................................................................................... 70

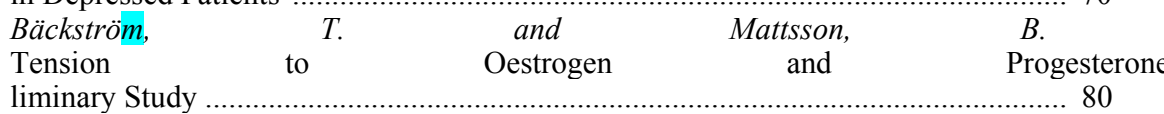

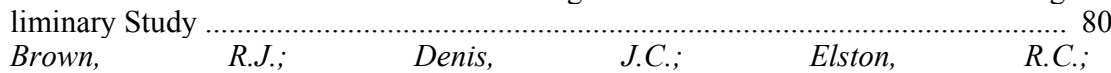

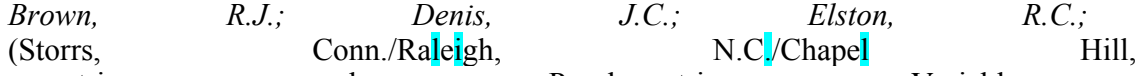

pometric

and Psychometric

Variables

Their Families .................................................................................... 87

in Functional Psychoses ............................................................................... 106

Helgason, T. and Asmundsson, G. (Reykjavik): Behaviour and Social Characteristics of

Young Asocial Alcohol Abusers.................................................................................. 109

Index

\begin{tabular}{|c|c|c|c|c|c|c|c|c|}
\hline during $R$ & üther, & $\begin{array}{r}E . \\
\text { Sleep }\end{array}$ & $\begin{array}{c}\text { Baarfi } \\
\text { and }\end{array}$ & & $\begin{array}{l}B, \text {, } \\
\text { with }\end{array}$ & $\begin{array}{l}\text { and } \\
\text { Thermal }\end{array}$ & Matussek, & $\begin{array}{r}N . \\
\text { Stimulation }\end{array}$ \\
\hline \multirow[t]{2}{*}{ (Umeâ): } & & Corre & c & & Symptoms & in & \multicolumn{2}{|c|}{ Pre-Menstrual } \\
\hline & Concer & ations & in & Blood & & Plasma. & A & Pre \\
\hline $\begin{array}{l}\text { Pollitzer, } \\
\text { in }\end{array}$ & N.C.): & $\begin{array}{l}\text { W.S.; } \\
\text { robands }\end{array}$ & $\begin{array}{l}\text { Prange, } \\
\text { Multivariate } \\
\text { with }\end{array}$ & A.J., & $\begin{array}{c}j r ., \\
\text { Analyses } \\
\text { Affective }\end{array}$ & and & $\begin{array}{l}\text { Wilson, } \\
\text { orders }\end{array}$ & $\begin{array}{r}\text { l. } C . \\
\text { Anthro- } \\
\text { and }\end{array}$ \\
\hline
\end{tabular}




\begin{tabular}{|c|c|c|c|c|c|c|c|c|c|c|c|}
\hline $\begin{array}{l}\text { Prange, } \\
\text { Lipton, } \\
\text { cago, } \\
\text { Polypeptid }\end{array}$ & $\begin{array}{l}\text { A.J., } \\
\text { M.A., } \\
\text { 111.): }\end{array}$ & $j r . ;$ & $\begin{array}{l}\text { Breese, } \\
\text { and } \\
\text { Parameters }\end{array}$ & $\begin{array}{l}\text { G.R.; } \\
\text { Plotnikoff, } \\
\text { of }\end{array}$ & $\begin{array}{c}\text { Jahnke, } \\
\quad \text { N.P. } \\
\text { Alteration } \\
.121\end{array}$ & $\begin{array}{l}\text { G.D.; } \\
\text { (Chapel } \\
\text { of }\end{array}$ & $\begin{array}{r}\text { Cooper, } \\
\text { PC }\end{array}$ & $\begin{array}{l}\text { Hill, } \\
\text { entobarbital }\end{array}$ & $\begin{array}{c}\text { Cott, } \\
\text { N.Cl/Raleigh, } \\
\text { Response }\end{array}$ & J.M.; & $\begin{array}{lr}\text { Wilson, } & \text { I.C.; } \\
\text { N.C./North } & \text { Chi } \\
\text { by } & \text { Hypothalamic }\end{array}$ \\
\hline
\end{tabular}

Varia .

132

\section{No. 3}

Ban, T.A. (Montreal): Nicotinic Acid in the Treatment of Schizophrenias. Practical and Theoretical Considerations ........................................................................... 13

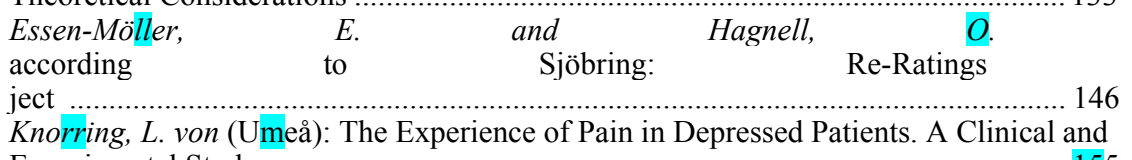

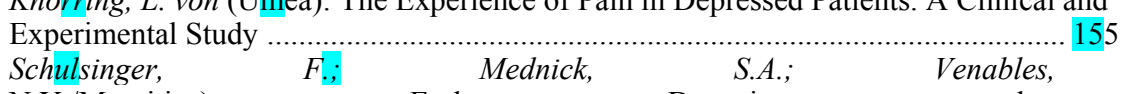

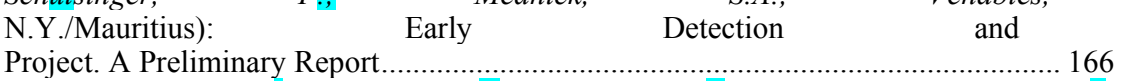

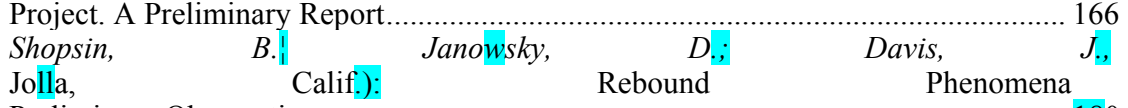
Jolla, Rebound

................. 18 Levitt, M.; Mendlewicz, J.; Fleiss, J.L., and Fieve, R.R. (New York, N.Y.): Norepinephrine Metabolism in Mouse Heart after Lithium and Rubidium Treatment „|, 188

Varia 196

\section{No. 4}

Metzig, E.; Rosenberg, S., and Ast, M. (Princeton, N.J./New York, N.Y.): Lateral Asymmetry in Patients with Nervous and Mental Disease. A Preliminary Study \197 $O$. W Jordan, $R$, Prom

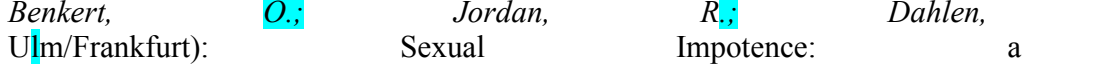

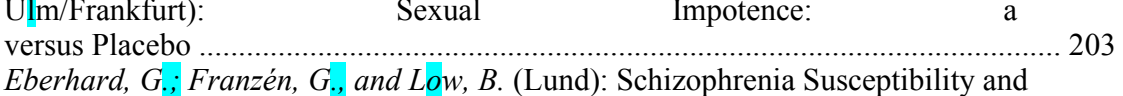

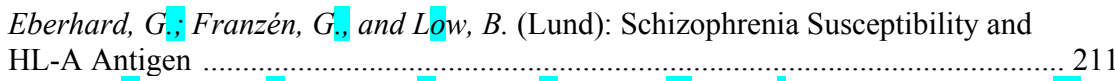
Saletu, B.; Saletu, M.; Brown, M.; Stern, J.; Sletten, I., and Ulett, G. (St. Louis, Mo.): Hypno-Analgesia and Acupuncture Analgesia: a Neurophysiological Reality? |. 218 Tissot, R. (Geneva): The Common Pathophysiology of Monoaminergic Psychoses: a New Hypothesis.

\section{No. 5}

Lovett Doust, J. W. and Podnieks, I. (Toronto): Comparison between Some Biological Clocks Regulating Sensory and Psychomotor Aspects of Perception in Man .... 261 Index

Brambilla, F,; Guerrini, A,; Rovere, C; Guastalla, A,; Riggi, $F_{\text {, }}$ and Recchịa, M. (Mi-

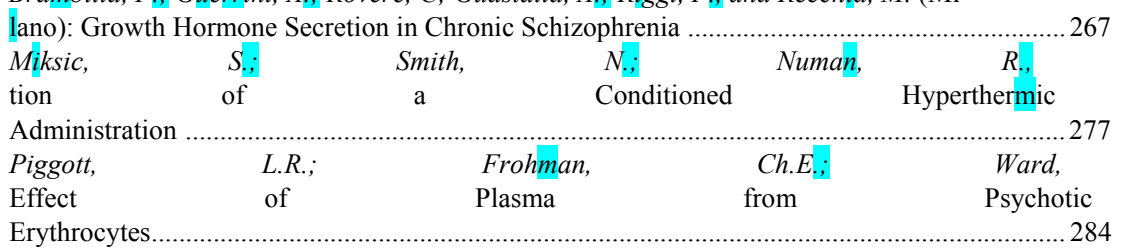

Kupfer, D.J.; Foster, F.G.; Detre, Th.P., and Himmelhoch, J. (Pittsburgh, Pa.): Sleep EEG and Motor Activity as Indicators in Affective States .................................................... 296 Abuzzahab, $\quad$ F.S., $\quad s r_{1}$ Dahlman, $\quad$ H.C., Three Year Double Blind Investigation

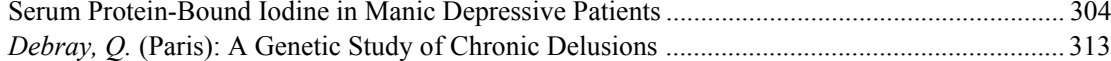

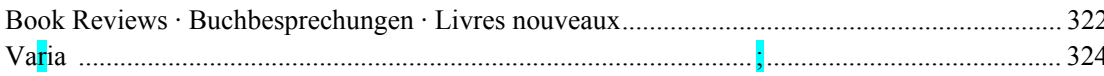

\section{No. 6}

Flemenbaum, A. (Lubbock, Tex.): Lithium and Amphetamine Hyperactivity in Rats. Differential Effect on $d$ and $1 \mathrm{r}$

Piraux, $A_{i} ;$ Jacquy, $J_{i}$; Lhoas, J.P.; Wilmotte, $J_{, \text {, }}$ and Noel, G. (Montigny-le-Tilleul) Regional Cerebral Blood Flow Variations in Mental Alertness.
Lund):

and

\section{'Normal'}

and

'Lesiona $\bar{\Gamma}$
Implications.

Traits

of

Personality

P.H.

Raman, of
Gershon,

A.C.,

and
Mental
(New
Patients

Bell,

Illness:

(New

York,

and

Manic

York, following N.Y./Chicago,

$111 / / \mathrm{La}$
Physostigmine.
$H \cdot G$.

Schneider

H.P.G

of and $\begin{array}{cc}\text { Gammel, } & G . \\ \text { LHRH } & \text { Nasa }\end{array}$
(München/ Spray

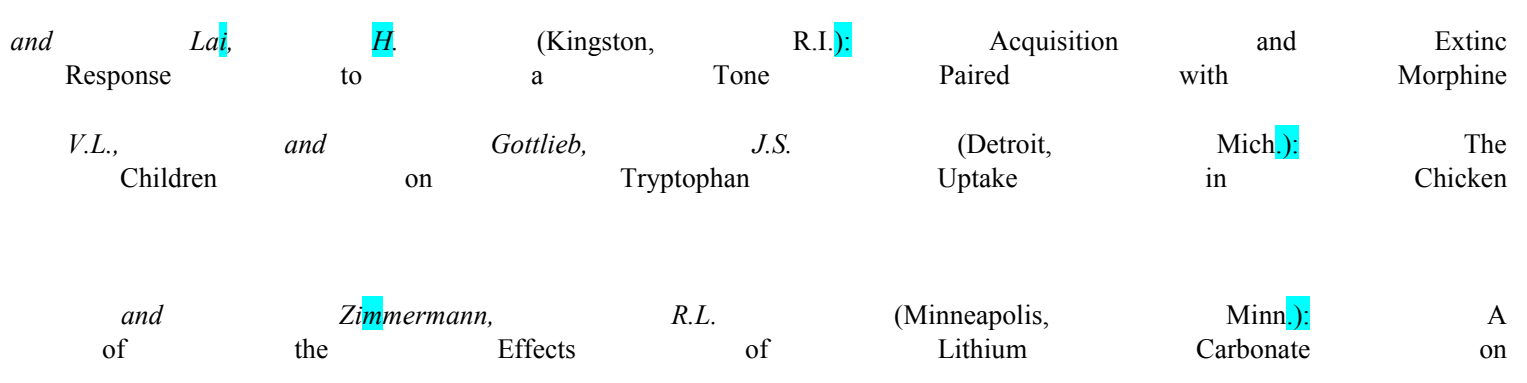


Christiansen, C; Baastrup, P.C., and Transb $<j>l, I$. (Glostrup/Hellerup/Copenhagen)

Osteopenia and Dysregulation of Divalent Cations in Lithium-Treated Patients \., 344

Carolei, A.; Margotta,. ., and Palladini, G. (Rome): Proposal of a New Model with

Dopaminergic-Cholinergic Interactions for Neuropharmacological Investigations \355

Luchins,

(Montreal):

The

Dopamine

Hypothesis

of

Schizophrenia

A

Critical

Anal

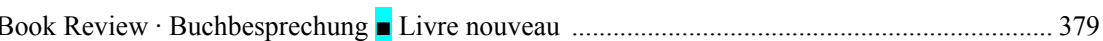

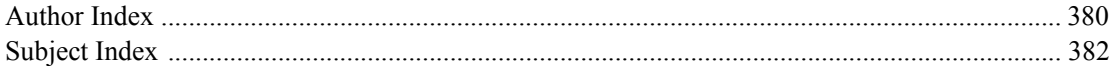

S. Karger · Basel · München · Paris · London · New York · Sydney Arnold-Böcklin-Strasse 25, CH-4011 Basel (Switzerland)

All rights, including that of translation into other languages, reserved. Photomechanic reproduction (photocopy, microcopy) of this volume or parts thereof without special permission of the publishers is prohibited.

() Copyright 1975 by S. Karger AG, Verlag fur Medizin und Natutwissenschaften, Basel Printed in Switzerland by Thür AG Offsetdruck, Pratteln 